\title{
Peningkatan Pemahaman Konsep Fisika Dasar Melalui Konflik Kognitif dengan Pertanyaan Tak Terduga
}

\author{
Muhammad Zuhdi*, Muh Makhrus \\ Program Studi Pendidikan Fisika, Universitas Mataram \\ *Email: mzuhdi@unram.ac.id
}

Received: 19 Oktober 2020; Accepted: 25 Desember 2020; Published: 26 Desember 2020

DOI: http://dx.doi.org/10.29303/jpft.v6i2.2121

\begin{abstract}
Inter-semester courses (KAS) Classes are identical to low grade classes with students whose level of understanding is inadequate. Students in this class usually have a misunderstanding of many concepts or misconceptions. Efforts that can be performed to improve the student's concepts is the method of conceptual change through unexpected questions, namely questions that most likely have not been thought of by students or the answers have not been thought of before by the student. The aim of this study is to determine the effectiveness of conceptual change learning with unexpected questions to improve understanding of concepts. This research was conducted in the inter-semester course class of 2018-2019 school year which was conducted in July 2019, with students from all study programs at the Department of Mathematics and Natural Sciences Education, Teaching and Education Faculty, at A University in Mataram City. The results of this study indicate that this method can significantly improve understanding of the concept. The treatment has successfully increasing the understanding of concept from $26.4 \%$ to $62.9 \%$.
\end{abstract}

Keywords: conceptual change; cognitive conflict; physics education

\section{PENDAHULUAN}

Kuliah fisika dasar adalah mata kuliah wajib bagi siswa jurusan Matematika dan Ilmu Pengetahuan Alam (PMIPA). di Fakultas Keguruan dan Ilmu Pendidikan (FKIP) Universitas Mataram. Jurusan Matematika dan Ilmu Pengetahuan Alam terdiri dari Pendidikan Fisika, Pendidikan Biologi dan Program Studi Pendidikan Kimia. Kuliah fisika dasar terdiri dari 3 SKS kuliah teori di kelas dan 1 SKS praktikum di laboratorium. Praktikum diadakan di laboratorium fisika di Jurusan Matematika dan Ilmu Pengetahuan Alam, FKIP, Universitas Mataram. Laboratorium fisika ini khusus untuk siswa yang mengambil jurusan Pendidikan Matematika dan Ilmu Pengetahuan Alam, sedangkan siswa dalam program studi dan jurusan lainnya melaksanakan praktikum fisika dasar di Laboratorium Fisika Dasar, Fakultas Matematika dan Ilmu Pengetahuan Alam (non-pendidikan) FMIPA, Universitas Mataram. Pemisahan ini didasarkan pada pertimbangan bahwa praktikum untuk jurusan pendidikan fisika memiliki tujuan yang berbeda dari jurusan di fakultas lain, yaitu untuk mengembangkan teori belajar dan praktikum sesuai kebutuhan saat proses belajar mengajar di sekolah.

Kuliah antar semester (Kuliah Antar Semester / KAS) sebelumnya disebut sebagai kuliah semester pendek. Kuliah ini awalnya hanya diadakan oleh beberapa universitas terkemuka untuk mensukseskan program percepatan menghasilkan insinyur. Karena kuliah semester pendek dirasa sangat membantu bagi mahasiswa untuk mempercepat penyelesaian studi mereka, maka perkembangan berikutnya, kuliah semester pendek diadakan oleh semua fakultas di universitas terkemuka ini. Pada akhirnya, hampir semua fakultas di hampir semua universitas dan perguruan tinggi mengadakan program KAS.

Persyaratan untuk mengikuti kuliah semester pendek ini adalah bahwa siswa pernah mengikuti kuliah, tetapi gagal untuk 
mendapatkan nilai yang ditargetkan. Peserta mahasiswa antar semester identik dengan mahasiswa berkemampuan rendah, meski tidak sepenuhnya demikian. Kadang-kadang kuliah ini diikuti oleh beberapa siswa pintar dengan strategi yang salah ketika mengambil kuliah sehingga mereka gagal mendapatkan nilai yang ditargetkan.

Penelitian ini dilakukan di kelas perkuliahan semester (KAS) program studi fisika dasar, diikuti oleh tiga program studi yaitu pendidikan fisika, pendidikan matematika, pendidikan biologi dan program Pendidikan Kimia. Semua siswa yang mengikuti kuliah ini telah menerima materi yang sama, yang diperoleh saat menghadiri kuliah sebelumnya.

Peserta program studi semester semester (KAS) identik dengan siswa dengan pemahaman konseptual yang buruk atau salah. Dalam penelitian ini, siswa peserta KAS diharapkan dapat meningkatkan pemahaman mereka tentang konsep dengan tepat dan benar. Metode pembelajaran yang digunakan dalam kuliah antar semester adalah perubahan konseptual.

Gardner (1999) menyatakan bahwa setidaknya ada tiga faktor sebagai hambatan utama bagi siswa dalam mencapai pemahaman konsep, yaitu: (1) pemilihan metode pembelajaran yang cenderung mentolelir cara unitary ways of knowing, (2) substansi kurikulum yang cenderung bersifat tidak kontekstual, dan (3) rumusan tujuan pembelajaran jarang berorientasi pada pencapaian pemahaman yang mendalam. Sistem pembelajaran yang tidak memberikan kesempatan bagi siswa untuk memahami konsep sains yang esensial akan menimbulkan kesalah-pahaman.

Hewson dan Hewson (2003) melakukan penelitian dengan membandingkan model pembelajaran perubahan konseptual dengan model pembelajaran konvensional. Hasil penelitian menunjukkan bahwa kelompok eksperimen mampu meningkatkan konsepsi ilmiah dan mengurangi kesalah-pahaman siswa secara signifikan bila dibandingkan dengan model pembelajaran dalam kelompok kontrol.

Salah satu pendekatan pembelajaran yang dirancang dengan fokus pada penanaman konsep di antara siswa adalah pembelajaran konseptual interaktif atau Interactive Conceptual Learning (ICL). Pendekatan ini memiliki 4 karakteristik utama, yaitu berfokus pada aspek konseptual, memprioritaskan interaksi kelas, menggunakan bahan ajar berbasis penelitian, dan menggunakan teks (Savinainen dan Scott, 2001). Hasil penelitian yang dilakukan oleh Rusdiana, et al. (2003), Yuyu R Tayubi, et al. (2004), dan Savinainen \& Scott (2002), terkait dengan penerapan pendekatan ini, menunjukkan bahwa penggunaan pendekatan pembelajaran ini dapat meningkatkan pemahaman siswa tentang konsep secara signifikan dibandingkan dengan penggunaan pembelajaran tradisional. Dalam pendekatan ini, dalam sesi pengenalan dan ekstraksi konsep, alat demonstrasi digunakan untuk menunjukkan berbagai fenomena fisik yang terkait dengan konsep yang sedang dipelajari.

Menurut teori pembelajaran konstruktivis, siswa tidak datang ke kelas dengan "kepala kosong", tetapi mereka sudah memiliki pengetahuan awal atau prakonsepsi yang berasal dari pengalaman mereka sendiri (Blizak et al. 2009; Suparno, 1999). Secara umum, pengetahuan awal atau prakonsepsi yang dimiliki oleh siswa cenderung berbeda dari konsep ilmiah yang disepakati oleh para ahli, meskipun beberapa sudah sesuai dengan konsep ilmiah (Wenning, 2005; Suparno, 2013). Dalam konteks ini, konsepsi siswa yang berbeda dari konsep ilmiah disebut kesalah-pahaman.

Materi yang memiliki banyak kesalahpahaman tentang pemahaman siswa adalah 
obyek penelitian ini. Materi ini tentang mekanika benda tegar, fluida dan termodinamika. Sebelum mengikuti kuliah inter-semester, siswa mendapatkan pre-tes pada materi kuliah, kemudian post-test dengan pertanyaan yang persis sama di akhir kuliah.

Metode pembelajaran yang digunakan di kelas adalah perubahan konseptual menggunakan pertanyaan tak terduga. Sarana pertanyaan tak terduga di sini adalah pertanyaan yang belum pernah dipikirkan sebelumnya oleh siswa atau pertanyaan yang kemungkinan besar siswa tidak tahu jawabannya.

Pertanyaan ini akan membuat siswa berpikir keras dan sangat tertarik untuk menjawab pertanyaan tersebut. Siswa cenderung berpikir keras untuk menyelesaikan masalah tetapi konsep yang salah membuat siswa gagal menjawab dengan benar. Pada kesempatan ini dosen kemudian memberikan jawaban alternatif yang lebih masuk akal kemudian memberikan pemahaman yang nyata tentang konsep tersebut, kemudian disatukan secara konseptual dan lebih jelas.

\section{METODE PENELITIAN}

Siswa ketika datang di sekolah tidak seperti kertas kosong, karena belajar tidak hanya dimulai dari sekolah tetapi sejak lahir dan sejak berinteraksi dengan lingkungan, sehingga ketika mereka mulai belajar di sekolah siswa sudah memiliki ide yang dibentuk pada berbagai topik, termasuk bagaimana mereka melihat dan menafsirkan dunia di sekitar mereka. Beberapa ide mirip dengan konsep ilmiah tetapi beberapa ide berbeda (Pertiwi, 2012). Ada dua proses pembelajaran, yaitu proses asimilasi dan akomodasi. Dalam proses asimilasi, siswa menggunakan konsep yang sudah ada untuk menafsirkan fenomena baru dengan perubahan kecil dalam bentuk penyesuaian, dalam hal ini konsep awal siswa tidak salah, hanya saja tidak lengkap, sehingga mereka harus mengembangkan konsep awal untuk lebih lengkap dan lebih menyatu. Dalam proses akomodasi siswa harus mengubah konsep awal mereka karena mereka tidak dapat menjelaskan atau menjawab fenomena baru, sehingga siswa harus menyingkirkan konsep awal mereka dan membentuk konsep baru yang dapat digunakan untuk menjelaskan masalah ini. Untuk mengubah konsep atau akomodasi, dibutuhkan beberapa kondisi sebagai berikut: 1. Siswa tidak puas dengan konsep awal. Siswa akan mengubah konsep mereka jika mereka percaya bahwa konsep lama mereka tidak dapat digunakan lagi untuk menjelaskan masalah dan fenomena baru. 2. Konsepkonsep baru harus dipahami, rasional dan untuk dapat memecahkan masalah dan fenomena baru. 3. Konsep baru harus dapat menyelesaikan masalah terlebih dahulu, dan juga konsisten dengan teori atau pengetahuan yang ada. 4. Konsep baru harus bermanfaat untuk pengembangan penelitian dan penemuan baru (Suparno, 2012).

Perubahan konsep akan terjadi jika siswa dihadapkan dengan keadaan tidak seimbang yang merupakan ketidak-cocokan antara konsep yang mereka miliki dan keadaan lingkungan sekitarnya, yang menyebabkan konflik dalam pikiran mereka. Jika ada ketidak-seimbangan, siswa didorong untuk mencari keseimbangan baru dengan proses akomodasi. Proses akomodasi akan membuat siswa menyatukan pengalaman luar dengan pengetahuan mereka dan konsep-konsep baru akan muncul. Ketika siswa dalam keadaan seimbang itu berarti bahwa siswa sudah pada tingkat intelektual yang lebih tinggi daripada sebelumnya (Dahar, 1996).

Pada awal kuliah antar semester, prates dilakukan dengan materi kinematika, dinamika, keseimbangan benda tegar, cairan 
dan termodinamika. Pertanyaan terdiri dari 30 pertanyaan dengan jawaban alternatif yaitu: pasti benar, pasti salah atau tidak yakin. Pertanyaan pra-tes ini kemudian digunakan untuk post-tes yang diberikan setelah menerima perlakuan di akhir kuliah. Jika skor post-test meningkat secara signifikan dibandingkan dengan skor pretest, maka proses pembelajaran berhasil.

Dalam topik kinematika, pertanyaan tak terduga yang diberikan adalah tentang memahami perbedaan kecepatan dan kelajuan. Dalam topik ini, pertanyaan diberikan tentang kecepatan dan laju seseorang yang berada di Ferris Well. Pertanyaannya adalah bagaimana kecepatan dan kelajuan orang ketika bergerak di Ferris Well. Berapakah kecepatan rata-rata dan kelajuan rata-rata.

Pada topik keseimbangan benda tegar, siswa ditanya pertanyaan tentang apa manfaat dan kegunaan memahami pusat massa. Sebagian besar siswa tidak mengerti bahwa pusat massa dua benda yang mengorbit satu sama lain menjadi pusat rotasi dua benda yang mengorbit. Sebagian besar siswa berpikir bahwa pusat orbit bulan ada di pusat bumi, sedangkan pusat sebenarnya dari orbit bulan adalah pusat massa gabungan antara bumi dan bulan. Lokasi pusat massa bukan di pusat bumi tetapi pada garis antara pusat bumi dan pusat bulan.

Pada topik fluida, siswa diberikan pertanyaan dari mana menuju ke mana cairan mengalir. Hampir semua siswa menjawab bahwa cairan mengalir dari tempat yang lebih tinggi ke tempat yang lebih rendah. Ini tidak salah tetapi tidak selalu benar, mengingat air juga dapat berpindah dari tempat yang lebih rendah ke tempat yang lebih tinggi ketika dipompa atau disemprotkan. Pada kesempatan ini dosen kemudian mengingatkan siswa bahwa yang selalu terjadi adalah cairan selalu mengalir dari tekanan tinggi ke tekanan rendah.

Dalam materi termodinamika, sebagian besar siswa tidak memahami pentingnya memahami suhu absolut. Keberadaan suhu absolut ini mempengaruhi suhu timbangan termometer lainnya. Ketika siswa diberi pemahaman bahwa bisa saja sebuah benda dengan suhu hingga jutaan derajat Celcius, maka siswa juga akan menganggap bahwa suhu benda juga bisa mencapai minus satu juta derajat Celcius.

Ketika siswa ditanya apakah bisa atau tidak obyek di alam semesta atau di laboratorium memiliki suhu minus 1000 derajat Celcius, sebagian besar siswa akan menjawab bahwa itu bisa terjadi. Padahal pada kenyataannya, suhu terendah suatu benda adalah 0 Kelvin atau minus 273 derajat Celcius sehingga tidak ada benda yang memiliki suhu di bawah suhu itu. Siswa kemudian bertanya mengapa ini tidak bisa terjadi. Pada kesempatan ini dosen kemudian memberikan pemahaman yang benar tentang konsep suhu absolut dan teori partikel kinetik. Benda dengan suhu 0 Kelvin maka tidak memiliki energi kinetik lagi, sehingga tidak ada lagi panas yang bisa diambil darinya sehingga suhunya tidak bisa lebih rendah. Pernyataan ini akan benar-benar tertuju pada siswa dan kemudian konsep yang mereka pahami dapat diperbaharui menjadi benar dan lebih lengkap dan lebih menyatu.

\section{HASIL DAN PEMBAHASAN}

Jawaban dari pertanyaan pre-test terdiri dari 3 pilihan yaitu: 1. yakin, jawabannya benar, 2. yakin, jawabannya salah dan 3. tidak yakin, apakah jawabannya benar atau salah. Siswa yang menjawab pilihan 1 ketika pernyataan itu salah, maka siswa disimpulkan memiliki kesalahpahaman. Dan jika siswa menjawab pilihan 2, meskipun pernyataan itu benar, 
maka siswa tersebut juga memiliki kesalahpahaman. Siswa yang menjawab pilihan 1 ketika pernyataan itu benar, maka siswa disimpulkan memiliki konsepsi yang andal. Dan jika siswa menjawab pilihan 2, maka pernyataan itu salah, maka siswa juga memiliki konsepsi yang dapat diandalkan. Jika siswa menjawab pilihan 3, maka disimpulkan bahwa siswa belum memiliki konsep pemahaman tentang materi yang ditanyakan dalam pertanyaan.

\section{Hasil}

Tabel 1. Hasil pre-test dan post-test

\begin{tabular}{cccc}
\hline & Miskonsepsi & $\begin{array}{c}\text { Kurang } \\
\text { pemahaman }\end{array}$ & $\begin{array}{c}\text { Konsepsi } \\
\text { ilmiah }\end{array}$ \\
\hline $\begin{array}{c}\text { pre-test } \\
\text { post- } \\
\text { test }\end{array}$ & $59.8 \%$ & $13.8 \%$ & $26.4 \%$ \\
\hline
\end{tabular}

Hasil pretest dan posttest ditunjukkan pada tabel 1. Dari hasil ini tampak bahwa metode pembelajaran mengubah konsep melalui pertanyaan tak terduga sebagai konflik kognitif dapat meningkatkan pemahaman siswa tentang konsep dalam kuliah antar semester.

\section{Pembahasan}

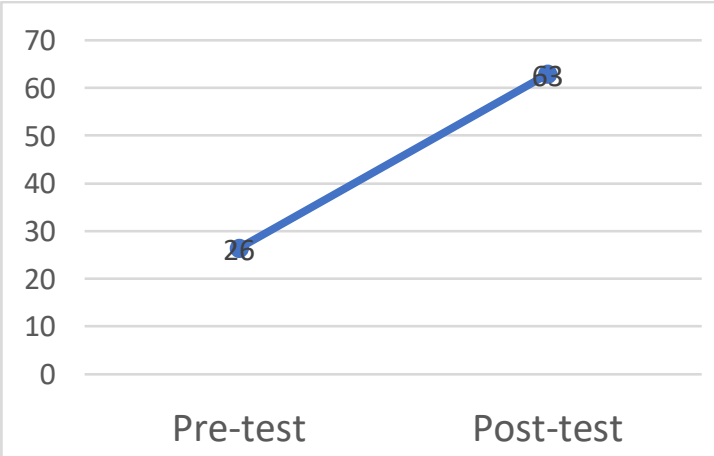

Gambar 1. Peningkatan prosentase konsep yang benar sebelum dan sesudah perlakuan

Nilai peningkatan konsep benar ditunjukkan pada tabel 1. Konsep yang benar yang dimiliki siswa meningkat dari $26,4 \%$ menjadi $62,9 \%$, sedangkan kurang-pahaman siswa menurun dari $59,8 \%$ menjadi $31,9 \%$.
Ini menunjukkan bahwa metode pembelajaran dalam kuliah antar semester dikatakan berhasil seperti yang diharapkan. Perlakuan semacam ini juga dapat mengurangi miskonsepsi mahasiswa peserta kuliah semester pendek.

Untuk mengurangi kesalahan konseptual pada siswa, guru harus mengembangkan strategi sesuai dengan kondisi perubahan konseptual untuk menciptakan konflik kognitif pada siswa, mengatur instruksi untuk mendiagnosis kesalahan dalam pemikiran siswa, dan membantu siswa untuk menghubungkan satu konsep dengan konsep lain (Baser), 2006). Peserta didik yang menyadari ketidakcocokan antara konsep ilmiah dengan konsep awalnya akan berupaya menyelesaikan masalah tersebut, sehingga meningkatkan kemampuan berpikirnya (Hidayatullah et al. 2018). Oleh karena itu, memilih strategi pembelajaran yang tepat sangat diperlukan dalam pembelajaran fisika.

\section{PENUTUP}

Metode pembelajaran perubahan konseptual melalui pertanyaan tak terduga dalam kuliah fisika dasar antar semester telah terbukti berhasil meningkatkan pemahaman konsep bagi peserta.

Penelitian lebih lanjut dengan metode ini dapat dilengkapi dengan analisis item untuk mengetahui masalah setiap topik dalam kuliah fisika dasar. Analisis barang berguna untuk mencari tahu materi dengan konsepsi yang paling salah dan topik dengan konsep yang dikenal oleh siswa.

\section{REFERENSI}

Baser, M. (2006). Effect of Conceptual Change Oriented Instruction on Students' Understanding of Heat and Temperature Concepts. Online Submission, 4(1), 64-79. 
Blizak, D., Chafiqi, F., \& Kendil, D. (2009, June). Students misconceptions about light in Algeria. In Education and Training in Optics and Photonics (p. EMA5). Optical Society of America.

Dahar, Ratna Wilis. (1996). Teori-Teori Belajar. Jakarta: Erlangga.

Gardner, H. (1999). The disciplined mind: What all students should understand. New York: Simon \& Schuster Inc.

Hewson, M. G., \& Hewson, P. W. (2003). Effect of Instruction Using Students' Prior Knowledge and Conceptual Change Strategies on Science Learning. Journal of Research in Science Teaching, 40. 586-598.

Hidayatullah, Z., Makhrus, M., \& Gunada, I. (2018). Analisis Tingkat Kemampuan Berpikir Kritis Gelombang Mekanik Melalui Pembelajaran Dengan Pendekatan Konflik Kognitif. Jurnal Pendidikan Fisika dan Teknologi, 4(2), 151-157. doi:http://dx.doi.org/10.29303/jpft.v4i $\underline{2.565}$

Pertiwi, D. (2012). Penerapan Model Perubahan Konseptual Dengan Menggunakan Protype Media Berbasis Cmaptools (PMBCT) Untuk Megurangi Miskonsepsi Siswa SMP. Skripsi Sarjana pada FPMIPA UPI Bandung.

Rusdiana, D., \& Tayubi, Y. R. (2003). Peningkatan Pemahaman Konsep Fisika melalui Pendekatan Pembelajaran Konseptual Interktif. Jurnal Pendidikan Fisika UPI, Laporan penelitian.

Savinainen, A., \& Scott, P. (2002). Using the Force Concept Inventory to monitor student learning and to plan teaching. Physics Education,37(1), 53.

Suparno, P. (1999). "Teori Perubahan Konsep dan Aplikasinya dalam Pembelajaran Fisika". Jurnal Ilmu Pendidikan, X(1): 15-26.
Suparno, P. (2012). Filsafat Konstruktivisme dalam Pendidikan. Yogyakarta: Kanisius.

Suparno, P. (2013). Miskonsepsi \& Perubahan Konsep Dalam Pendidikan Fisika. Jakarta : PT. Grasindo.

Wenning, C. J. (2005). Minimizing resistance to inquiry-oriented science instruction: The importance of climate setting. Journal of Physics Teacher Education Online, 3(2), 10-15. 